Volume and Issues Obtainable at Center for Sustainability Research and Consultancy

Sustainable Business and Society in Emerging Economies

ISSN:2708-2172 \&(E):2708-2504

Volume 3: Issue 3, September 2021

Journal homepage: www.publishing.globalcsrc.org/sbsee

\title{
Employee Well being and Work Life Balance as a function of Job Satisfaction: The Moderating role of Organizational Citizenship Behavior
}

*Muhammad Adnan, Azteca University (UA), Mexico. Universidad Central de Nicaragua, Republic of Nicaragua (North America). National College of Business Administration \& Economics (NCBA\&E) Lahore, Multan Sub-campus, Pakistan

Ayesha Bakhtawar, Air University (AUMC), Multan Campus, Pakistan

Rakia Tul Zahra, National College of Business Administration \& Economics (NCBA\&E) Lahore, Multan Sub-campus, Pakistan

*Corresponding author's email address: dr.adnanmalik1989@gmail.com

ARTICLE DETAILS

History

Revised format: May 2021

Available Online: July 2021

\section{Keywords}

Employee Well-being, Work Life Balance, Job Satisfaction, Organizational Citizenship Behavior, and Healthcare Centers.

Jel Classification

M1, M11

\section{ABSTRACT}

Purpose The goal of this study is to investigate that how Employee Well-Being and Work-Life Balance affected Job Satisfaction in healthcare centers with the moderating role of Organizational Citizenship Behavior.

Design/Methodology/Approach: Research was carried out in a quantitative approach. The healthcare centers of Multan region were chosen at random. Using a convenient sampling strategy, a questionnaire was created to collect data from different healthcare centers situated in Multan region. The Cronbach's Alpha and Discriminant Validity were used to assess the questionnaire's reliability in the pilot phase. Descriptive and inferential statistical techniques (using Smart PLS) were used to assess quantitative data.

Findings: Employee Well-being and Job satisfaction have a positive relationship, whereas Work-Life Balance and Job satisfaction have a negative relationship, according to the results of this study. Organizational Citizenship Behavior (OCB) moderates Employee Well-being and Work Life Balance to Job satisfaction. Employee Well-Being is one of the major strengths for employee productivity, according to the findings of this research. When professionals practice Organizational Citizenship Behavior, employees' job satisfaction begins to rise in healthcare centers.

Implications/Originality/Value: This study was a complete report on Multan's healthcare centers that will be highly beneficial and instructive for policymakers and administration staff of healthcare centers for employee's development, and for researchers in the Multan region to alter programs and policies according to the requirement for achieving goals 


\section{OPEN ACCESS}

(C) 2021 The authors, under a Creative Commons Attribution-

NonCommercial- 4.0

Recommended citation: Adnan, M., Bakhtawar, A. and Zahra, R. T., (2021). Employee Well being and Work Life Balance as a function of Job Satisfaction: The Moderating role of Organizational Citizenship Behavior. Sustainable Business and Society in Emerging Economies, 3 (3), 217-229.

\section{Introduction}

Employee Well-Being is a flexible concept that differs widely among generations, locations, countries, social norms, and cultures. In the scientific literature, several phrases are often used that indicate the same thing but stress slightly different aspects of happiness. Well-Being can be defined as the provision of both material and spiritual goods (Qi \& Wu, 2018). A person's sense of well-being is also a feeling or condition of happiness (Guest, 2017). According to previous research, employees' WLB (Boxall \& Macky, 2014) is viewed as a fundamental condition for experiencing well-being (Boxall \& Macky, 2014). 2017 (Mishra \& Kapoor). Simultaneous to the increasing importance of Employee Well-Being and WLB, it is essential to understand the links between these disciplines and find the most effective methods for providing the most desirable advantages, not only for the individual but also for the organization.

Various researches has associated Job Satisfaction to enhance professional performance, higher incomes, increased commitment, and work efficiency (Robertson \& Cooper, 2010; McCarty et al., 2011). In this post, we look at how WLB affects employee job satisfaction and how Employee Well-Being affects Job Satisfaction. We hypothesize that there is a strong association between Employee Well-Being and Job Satisfaction. As a result, we hypothesize in this study that Organizational Citizenship Behavior (OCB) moderates Job satisfaction (JS).

According to our research and point of view, long work hours view outcome in lower satisfaction and an inability to spend equal time to one's family and personal life. He eventually leads to a reduced degree of contentment, this has a negative impact on his job and personal happiness. Working hours, happiness level, satisfied with working hours, difference of personal commitment, and proper usage of free time are among the survey items. According to the previous study, each individual has a unique level of enjoyment. We will assess overall life satisfaction, as well as the impact of Employee Well-Being and Work-Life Balance, using the moderating function Organizational Citizenship Behavior.

\section{Background of the Study}

In recent years, the concept of an Employee's Well-Being and Job Satisfaction has gained prominence and has become strategically significant for enterprises around the world. Work-life balance programmers, like the monetary benefits supplied by the company, have become a desirable metric for job searchers. Competition between businesses is increasing in the current period of globalization, as is the rate of global economic growth. Companies demand that the people who work for them be able to compete, survive, and win (Ganapathi, I. M. D., and Gilang, A.) (2016). In order to meet the goals, set forth, several businesses have introduced Work-Life Balance.

Employee Well-Being was integrated as a quality marker of Job Satisfaction in our study, which was based on a systems approach (Montgomery et al., 2019). Montgomery and colleagues reveal how an individualism approach ignores the channels of (chronic) pressures, which are commonly associated with the worksite (such as employee shortages).

Although if individual experience well-being indexes (such as exhaustion), collaborative well-being responses among employees are typically a response to shared job characteristics (such as different stress factors). As a result, while individualized therapies may be beneficial to employees, they are less likely to 
have a long-term impact than company-wide solutions (Montgomery et al., 2019).

\section{Problem Statement}

Employee Well-Being is a big concern for many organizations, according to a recent research Employee happiness has been shown to have a considerable effect on turnover (Page and Vella-Brodrick, 2009), productivity and additional expenses relating to organizational sustainability (Page and Vella-Brodrick, 2009; Wright et al., 2007 (Rau \& Griffin, 1999). Turnover is a major concern for businesses nowadays, owing to the high costs associated with it. Employees will be affected by role conflicts, which will guide to Job Satisfaction and, in extreme circumstances, health and psychological well-being, as well as employment withdrawal and turnover (Rau and Hyland, 2002).

Work-Life Balance has become a more pressing problem for both businesses and employees in recent years. Employee productivity is often tied to work-life balance, which largely concerns with a person's ability to priorities between work and his lifestyle, social life, health, and family, among other things. Employees are pushed to work more hours as a result of unpredictable workflows and incredibly quickly work settings with short timelines, which is also a cause for concern. As a result, many people have stated that they are overwhelmed and that their work-life balance is off.

\section{Significance of Study}

The conclusions of this study will aid in determining how to obtain high levels of Job Satisfaction. The information collected from this study on the impact of employee perks on Job Satisfaction will help banks better understand how to turn their workers into assets, resulting in increased productivity and a long-term competitive advantage

\section{Conceptual Framework}

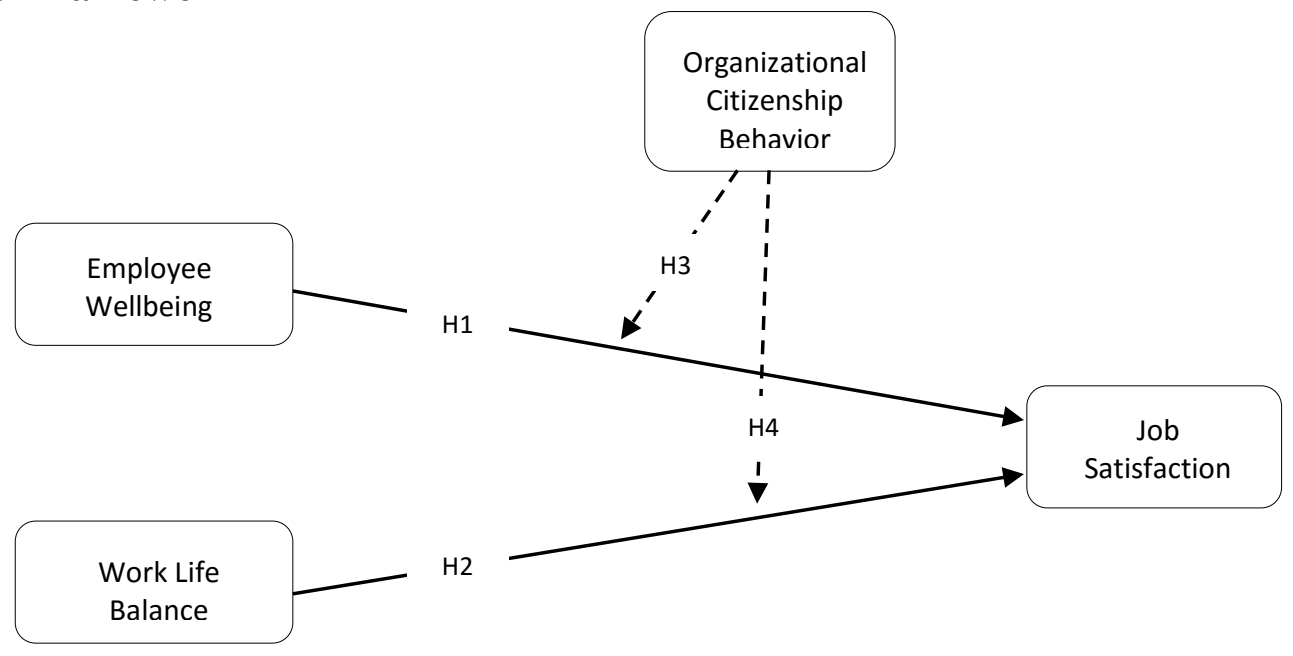

Figure 1: Conceptual Framework

\section{Literature Review \\ Employee Well-Being}

The fact humans experience at work is an important issue for any firm to grasp, and not simply for humanitarian reasons, but also because of the costs involved associated with poor health. Sickness absenteeism and lower productivity at work have been linked to a lower sense of Well-Being. It's vital to look at well-being in the context of the workplace to have a clear picture of how it relates to the workplace, allowing companies to promote Well-Being among their employees. 


\section{Work Life Balance}

Work life balance represents an equal investment in both the workplace and semi elements of life. According to Greenhaus et al. (2003), WLB contains three components: (1) time balance (comparable time being spent on family and work), (2) involvement balanced (intellectual participation in business family commitments), and (3) satisfaction balance (alike contentment with family and work).

\section{Job Satisfaction}

Job satisfaction refers to people's thoughts and feelings about their specific employment. Employees' job satisfaction levels can range from extremely satisfied to highly dissatisfy. They also have personal opinions on their task world in general. People can also have thoughts and emotions about their jobs, such as the sort of work they do, their work colleagues, bosses, or supervisors, and expect to be paid (George et al., 2008).

\section{Organization Citizenship Behavior}

Organ (1988) describes OCB as "voluntary work-related activities that are unrelated to the structured organizational incentive system and, in average, make effective running of the organization." OCB also extends further than performance indicators provided in a company's formal job description. Furthermore, it (OCB) demonstrates employee behaviors that go above and beyond the company must meet work demands to help colleagues. (Lovell, Kahn, Anton, Davidson, Dowling, et al., 1999).

\section{Hypothesis Development}

\section{Relationship of Job satisfaction with Employee Well-Being}

The literature has recognized the significance of Job satisfaction in terms of Employee Well-Being (See, for example, Faragher, Cass, and Cooper, 2005; Iaffaldano and Muchinsky, 1985; Judge, et al., 2001; Warr, 2009). Employees who are dissatisfied have poorer a sense of well-being in specifically, report higher levels of anxiety and despair. When observing Employee Well-Being, which can be classed as intrinsic or extrinsic, are of particular importance. Employees' internal job satisfaction relates to their feelings regarding the nature of their job activities, whilst external motivational pleasure belongs to feelings regarding features of their workplace that are unrelated to their work responsibilities. Hirschfeld and Rothmann, 2000; Rothmann, 2008). External factors directly affect workplaces, coworkers, compensate, interactions between managers and employee, the strategy your organization takes, regular hours, and stable employment, whereas internal factors include flexibility in choosing your own operation, applaud and acknowledgement work, number of responsibility, chances to use attributes, possible of advancement, and focus to your recommendations, and wide range of work (Warr et al., 1979).The use of these composites to look at satisfaction and well-being gives us a better understanding.

H1: There exists a significant relationship between Employee Well-Being and Job Satisfaction.

\section{Relationship with Work Life Balance (WLB) and Job Satisfaction (JS).}

An agreeable sensation about a job that arises from a study of its characteristics" is how job satisfaction is defined. Several variables have been described in the literature as determinants of Job Satisfaction, and several researchers have concentrated on job satisfaction. WLB has been shown to be a positive association between Job Satisfaction On the other hand, Findings on the influence of a bad Work-Life Balance or work overload on Job Satisfaction tend to focus on the impact of a poor Work-Life Balance or workplace dispute on Job Satisfaction. As per a study, employees who face controversy between their task and - anti problems are far less satisfied at work and in daily existence. An imbalance between work and non-work was identified to be the leading cause of job dissatisfaction in a survey of bus drivers. Other studies found a negative connection between work conflict and job satisfaction of employees.

H2: There is a significant relationship between Work Life Balance and Job Satisfaction.

Moderation between Employee Well-being (EWB) and Job Satisfaction (JS) 
William \& Anderson discovered both extrinsic and intrinsic Job Satisfaction have positive relationships with each of the OCB elements (1991). They utilized a solitary indicator to assess work satisfaction and modified 3 components of the OCB rate to create a comprehensive score (altruism, conscientiousness, and sportsmanship). As according Ahmad (2006), four employee attitudes have a positive and direct impact on academicians' citizenship practices in Malaysia; Firm Strong commitment, career satisfaction, procedural fairness, and egalitarianism are all examples of justice. Furthermore, involvement in the workplace, commitment to the organization, and ethical culture were all linked to OCB in a study of employees in a health-care Unit (Othman, 2002).

H3: Organizational Citizenship Behavior positively moderate the relationship between Employee Wellbeing and Job Satisfaction.

\section{Moderation with Work Life Balance (WLB) and Job Satisfaction (JS)}

WLB refers to those who are evenly active in work and family life and are content in both. Work-life balance appears to have a significant impact on Corporate Citizenship activities, according to a study. Social obligations, individual matters, goal setting, time work, remuneration, and benefits were examined as factors of Work-Life Balance, whereas Organizational Citizenship Behavior qualities included generosity, self - control, tolerance, and civilized behavior. Workers who can balance work life and personal life have fewer responsibilities, higher performance, and better corporate citizenship, all of which influence productivity. People who believe they have a good work-life balance are less likely to leave the organization and more likely to take part in corporate citizenship projects.

As per research, based on a survey of 98 participants, there is a significant and positive relationship between Work-Life Balance and Job Satisfaction between many educational workmates in academic institutions. Work-Life Balance refers to the aspects of managing time, whereas Job Satisfaction refers to aspects such as the job itself, salary, career progression, monitoring, and companions. Employees will accomplish Work-Life Balance, according to research, if they are satisfied and successful in various endeavors, which will boost the variables that improve job satisfaction and efficacy at work and at home. Components that inhibit job happiness and effectuality at home and in the workplace, on the other hand, will have an unfavorable effect on the WLB.

\section{Organizational Citizenship Behavior (OCB) and Job Satisfaction (JS)}

As per Organ and Bateman, all components of Job Satisfaction, including remuneration, development chances, oversight, personality, and colleagues, are related to organizational contextual performance in a good way. Organizational Citizenship Behavior refers to the attributes of generosity, self - control, gentility, and moral responsibility, whereas job satisfaction belongs to factors such as work, wages, achievements, management, and colleagues. Organizational Citizenship Behavior (OCB) refers to the activities by members of the organization or workers that are not specifically rewarded or prohibited. The employee's work description does not specify OCB.

H4: Organizational Citizenship Behavior positively moderate the relationship between Work Life Balance and Job Satisfaction.

\section{Theory of Planned Behavior (TPB)}

Theory of Planned Behavior (TPB) first was presented in 1980 as just a tool to determine a person's desire to perform a given behavior at a specific moment in time. The hypothesis was created to encompass all human activities that are subject to self-control. This technique heavily depends on behavioral control; one's personal assessment of the risks and advantages of the intended outcome, as well as one's judgment of the likelihood that the behaviors would generate the desired result, influence one's intentions. According with TPB, behavioral performance can be determined by both intent (real purpose) and ability (behavioral control). Beliefs are classified into three types: cognitive, rule, and regulating. 


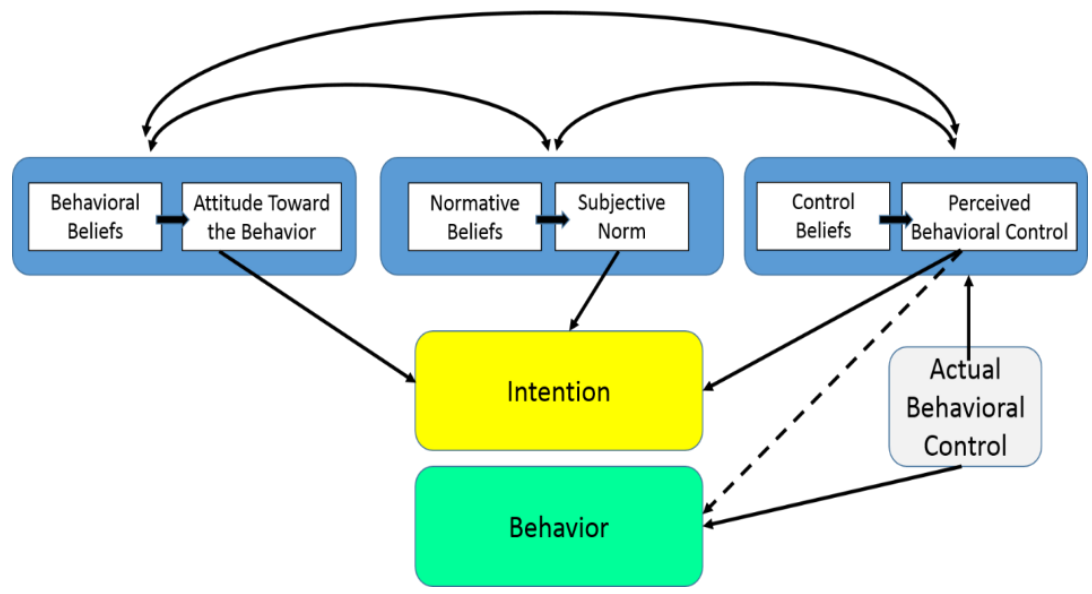

Figure 2: Theory of Planned Behavior (framework)

\section{Methodology}

The goal of this research was to see how Employee Well-Being and Work-Life Balance affected employee's contentment, well-being, and work satisfaction, as well as the moderating function of Organizational Citizenship Behavior in the links between Well-Being and WLB and Job Satisfaction. For the data analysis Smart PLS 3.2.8 software were employed because this technique is extensively utilized in the scientific community and is more robust than standard regression analysis (Amram \& Dryer, 2008). Because of the accessibility of access to respondent information, as well as time and expense constraints, the researcher chose the Healthcare Center. The employees working in Multan's healthcare centers who deal directly with patients were chosen for this study. Different healthcare centers were chosen at random for this study's sample. Finally, 220 employees from various healthcare centers were asked to participate in this study. The Technique used in the research is convenient sampling. This study used convenient random sampling with the different healthcare centers. A total of 220 employees were chosen at random from each institution to produce the sample size.

For this study, primary data was collected. To acquire primary data, the researcher employed a designed structured questionnaire. A five-level Likert Scale was used to assess the respondents (1=strongly disagree to $5=$ strongly agree).

\section{Research Implements and Scale Measures Employee Well-being}

The study used a measure that has previously been used in research undertaken by others to assess the well-being of healthcare employees (Skevington et al., 2004). The model is intended in a 5.0-point Likert Scale, with 1: Strongly Disagree, 2: Disagree, 3: Neutral, 4: Agree, and 5: Strongly Agree.

\section{Work Life Balance}

While trying to evaluate the Work Life Balance provided to employees of healthcare centers, the present study adapted a scale previously used in a study conducted by (Daniels and McCarraher Industrial Society, 2000), which was rooted with the following scale: 1: Strongly Disagree, 2: Disagree, 3: Neutral, 4: Agree, and 5: Strongly Agree.

\section{Job Satisfaction}

Current survey adapted the scale used earlier in the research official investigation by (Smith, 1969) with 5.0-point Likert Scale grounding with to assess the Job Satisfaction founded in the healthcare centers. 1: Agree, 2: Disagree, 3: Neutral, 4: Agree, 5: Strongly Agree

\section{Organizational Citizenship Behavior}

Present survey evolved the scale used earlier in the research examination directed by (Organ, 1988; Podsakoff et al., 2009) with 5.0-point Likert Scale attaching with to assess the Organizational Citizenship 
Behavior formed in the healthcare centers. $1=$ Strongly Disagree, $2=$ Disagree, $3=$ Neutral, $4=$ Agree, and $5=$ Strongly Agree.

\section{Statistical Analysis}

\section{Descriptive Statistics and Inter-Construct Correlation}

Table 1 depicts the strength of the correlations among the latent variables by showing the Mean (M), Standard Deviations (STDEV) of a sample, T-Statistics, and their accompanying P-values.

Table-1: Descriptive Statistics

\begin{tabular}{|c|c|c|c|c|}
\hline Hyp. & Relationships & Sample & Mean & STDEV \\
\hline H1 & Employee Well-being (EWB) $\rightarrow$ Job Satisfaction (JS) & 0.336 & 0.334 & 0.074 \\
\hline $\mathrm{H} 2$ & Work Life Balance (WLB) $\longrightarrow$ Job Satisfaction (JS) & 0.212 & 0.217 & 0.064 \\
\hline $\mathrm{H} 3$ & $\begin{array}{l}\text { Employee Well-being (EWB)*Organizational Citizenship Behavior } \\
(\text { OCB }) \rightarrow \text { Job Satisfaction (JS) }\end{array}$ & -0.171 & -0.165 & 0.079 \\
\hline H4 & WLB $* \overrightarrow{\mathrm{OCB}} \longrightarrow$ Job Satisfaction $(\mathrm{JS})$ & 0.125 & 0.118 & 0.081 \\
\hline EX1 & $\begin{array}{l}\text { Employee Well-being }(\text { EWB } \longrightarrow \quad \text { Organizational Citizenship } \\
\text { Behavior }(\mathrm{OCB})\end{array}$ & 0.545 & 0.547 & 0.071 \\
\hline EX2 & $\begin{array}{l}\text { Organizational Citizenship Behavior }(\mathrm{OCB}) \longrightarrow \text { Job Satisfaction } \\
\text { (JS) }\end{array}$ & 0.402 & 0.399 & 0.075 \\
\hline EX3 & $\begin{array}{l}\text { Work Life Balance }(\mathrm{WLB}) \longrightarrow \quad \text { Organizational Citizenship } \\
\text { Behavior }(\mathrm{OCB})\end{array}$ & 0.297 & 0.297 & 0.074 \\
\hline
\end{tabular}

In Table 2 the Coefficient Correlation refers to the strength of a linear relationship between two variables. A number of linear correlations $<0$ indicates a positive correlation. A value $>0$ suggests a negative association. All of the values revealed are positive between 0.676 and 0.792 , indicating that almost all of the constructs explain the relationship between 67 and 79 percent of the time, with no multi-collinearity.

Table-2: Inter-Construct Correlation

\begin{tabular}{|c|c|c|c|c|c|c|}
\hline & EWB $* \mathbf{O C B}$ & ES & EWB & OCB & WLB $* \mathbf{O C B}$ & WLB \\
\hline EWB $* \mathbf{O C B}$ & 1.000 & 0.308 & 0.393 & 0.411 & 0.907 & 0.469 \\
\hline Employee Satisfaction (ES) & & 1.000 & 0.774 & 0.774 & 0.314 & 0.707 \\
\hline Employee Well-Being (EWB) & & & 1.000 & 0.769 & 0.377 & 0.755 \\
\hline $\begin{array}{l}\text { Organizational Citizenship Behavior } \\
\text { (OCB) }\end{array}$ & & & & 1.000 & 0.374 & 0.709 \\
\hline WLB*OCB & & & & & 1.000 & 0.414 \\
\hline Work Life Balance (WLB) & & & & & & 1.000 \\
\hline
\end{tabular}

Inter-Construct Correlation depicting the correlation of latent variables with other latent variables have been illustrated in Table 2.

\section{Measurement Model}

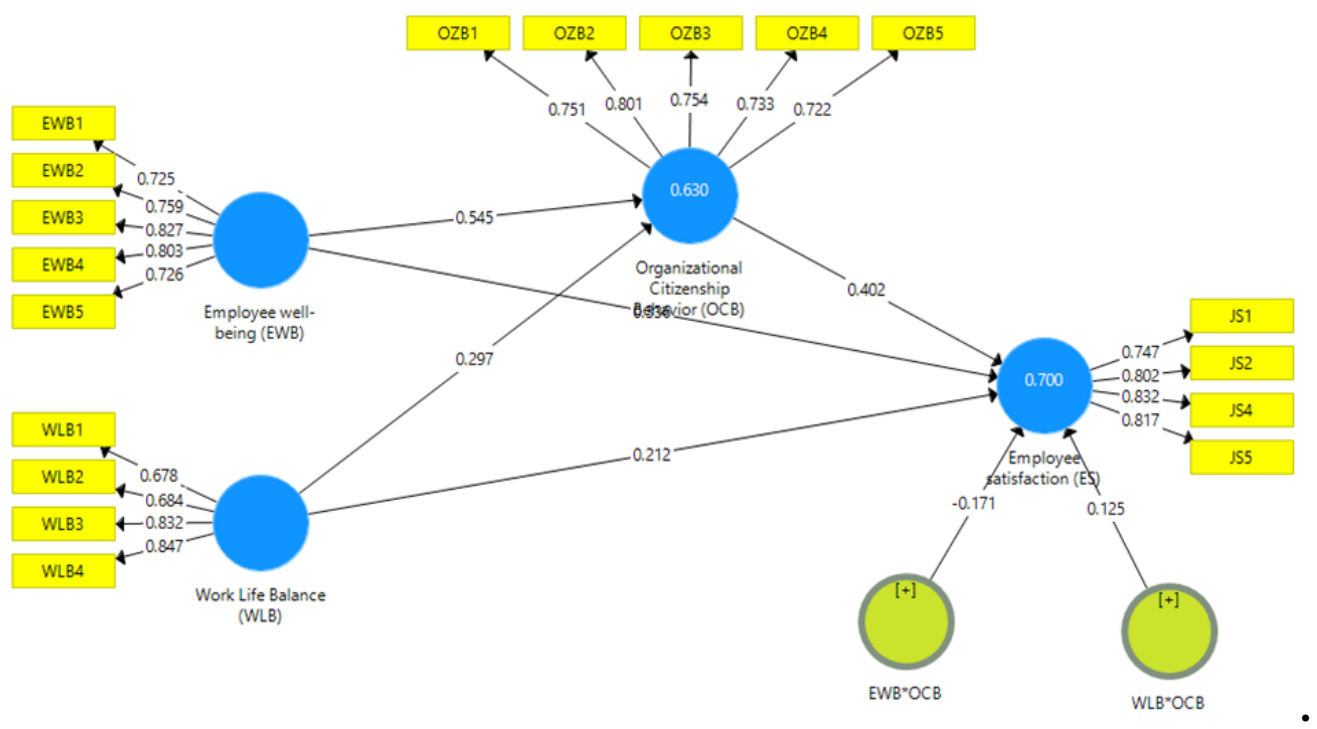




\section{Construct Reliability and Validity}

Figure 03: Measurement Model

Table-4 show a comprehensive investigation of the data's reliability and validity. Huang et al. (2013) affirmed that AVE values is $>0.05$, and Hadi et al. (2016) argued that the value of Factor Loadings must be $>0.5$, means that the value is correct. The values of AVE and Factor Loadings in this research exceeded the 0.05 threshold, indicating that the data is correct. According to Black et al. (2014), the Composite Reliability (C.R) is greater than 0.45, implying that C.R value exceeds this limit, suggesting that the data is reliable. As according Nunally (1978) Cronbach's Alpha is considered credible when it is around 0 and 1, Cronbach's Alpha results of the study show that almost all of the values are less than 0.9, which is generally true.

Table-4: Construct Reliability and Validity

\begin{tabular}{llllll}
\hline Construct(s) & Cronbach's Alpha & C.R & AVE & Mean & STDEV \\
\hline $\begin{array}{l}\text { Employee Well-Being (EWB) } \\
\text { Job Satisfaction (JS) }\end{array}$ & 0.827 & 0.878 & 0.592 & 15.571 & 4.662 \\
$\begin{array}{l}\text { Organizational Citizenship } \\
\text { (OCB) }\end{array}$ & 0.813 & 0.877 & 0.64 & 12.329 & 4.623 \\
Work Life Balance (WLB) & 0.809 & 0.867 & 0.567 & 12.128 & 4.286 \\
& 0.758 & & & & \\
\hline
\end{tabular}

According to Hair et al. (2017), while measuring the Composite Reliability, the indicator loading values are greater than 0.70, and the values for Average Variance Extracted (AVE) and indicator reliability should be greater than 0.50 . Table 5 shows the values of cross loading for each concept in the current study.

Table-5: Outer Factor Loadings

\begin{tabular}{|c|c|c|}
\hline Construct(s) & Factors & Loadings \\
\hline \multirow{5}{*}{ Employee well-being (EWB) } & EWB1 & 0.725 \\
\hline & EWB2 & 0.759 \\
\hline & EWB3 & 0.827 \\
\hline & EWB4 & 0.803 \\
\hline & EWB5 & 0.726 \\
\hline \multirow[t]{2}{*}{$\mathrm{WLB} * \mathrm{OCB}$} & $(\mathrm{EWB}) *(\mathrm{OCB})$ & 1.325 \\
\hline & JS1 & 0.747 \\
\hline \multirow{4}{*}{ Job Satisfaction (JS) } & JS2 & 0.802 \\
\hline & JS3 & DELL \\
\hline & JS4 & 0.832 \\
\hline & JS5 & 0.817 \\
\hline \multirow{5}{*}{$\begin{array}{l}\text { Organizational } \\
\text { (OCB) }\end{array}$} & OZB1 & 0.751 \\
\hline & OZB2 & 0.801 \\
\hline & OZB3 & 0.754 \\
\hline & OZB4 & 0.733 \\
\hline & OZB5 & 0.722 \\
\hline \multirow{5}{*}{ Work Life Balance (WLB) } & WLB1 & 0.678 \\
\hline & WLB2 & 0.684 \\
\hline & WLB3 & 0.832 \\
\hline & WLB4 & 0.847 \\
\hline & WLB5 & DELL \\
\hline EWB*OCB & $(\mathrm{WLB}) *(\mathrm{OCB})$ & 1.396 \\
\hline
\end{tabular}

The HTMT (Discrimination Validity) ratio was used to emphasize the differentiate ratio and its terms, that 
must be less than one to accept (Wang et al. 2015). Furthermore, the Fornell-Larcker criterion and CrossLoadings are used to determine discriminate Validity. The Correlation value with other latent variables should be less than the square root of Average Variance Extracted (AVE) for each latent variable, according to the Fornell-Larcker criterion. Additionally, the Outer Loading for a construct indicator should be larger than the Cross Loading with all other variables (Hair et al., 2017). The results for Discriminant Validity under Fornell-Larcker criterion has been exhibited in Table 6.

Table-6: Discriminant Validity

\begin{tabular}{lllllll}
\hline HTMT & EWB*OCB & JS & EWB & OCB & WLB*OCB & WLB \\
\hline EWB*OCB & 1 & & & & & \\
JS & 0.308 & 0.800 & & & & \\
EWB & 0.393 & 0.774 & 0.769 & & & \\
OCB & 0.411 & 0.774 & 0.769 & 0.753 & & \\
WLB ${ }^{\text {OCB }}$ & 0.907 & 0.314 & 0.377 & 0.374 & 1.000 & \\
WLB & 0.469 & 0.707 & 0.755 & 0.709 & 0.414 & 0.764 \\
\hline
\end{tabular}

The analysis shows that objects have a satisfactory level of Composite Reliability and also reliability, with substantial Factor Loadings (>0.70), acceptable AVE (>0.50), good indicator reliability (>0.50), and a higher level of Internal Consistency in each of the four latent variables (Employee Well-being, Work Life Balance, Job Satisfaction, Organizational Citizenship Behavior), having the values of Cronbach's Alpha and Composite Reliability values tend to range between 0.848 and 0.878 . It was found that all four latent variables discriminated each other because scale met the criteria for evaluating Discriminant Validity based on the Fornell-Larcker criterion as well as higher outer loading.

\section{Coefficient of Determination $\left(\mathbf{R}^{2}\right)$}

The next stage in smart PLS is to study the structural model's validity after reviewing the assessing models. The Determination Coefficient $\left(\mathrm{R}^{2}\right)$ tends to reflect the integrated effect of exogenous construct latent variables on a target latent endogenous construct with an acceptable range of values between 0 and 1, with higher values indicating higher explanation of the research systematic framework (Joseph F Hair et al., 2019). The $\mathrm{R}^{2}$ values for JS (0.700) and OCB (0.630) are good and moderate, but not strong, as shown in Table 6.

\begin{tabular}{lll}
\multicolumn{3}{c}{ Table-6: $\mathrm{R}^{2}$ and $\mathrm{R}^{2}$-Adj. } \\
\hline JS & $\mathbf{R}^{\mathbf{2}}$ & $\mathbf{R}^{\mathbf{2}}$ - Adj. \\
OCB & 0.700 & 0.693 \\
& 0.630 & 0.626 \\
\hline
\end{tabular}

Coefficient of Effect Size $\left(\mathbf{F}^{2}\right)$

To estimate the change in the $\mathrm{R}^{2}$ value, the value of $\mathrm{F}^{2}$ for a latent construct must be examined (Sarstedt et al., 2017). Table 7 shows that the effect of OCB on JS was found to be substantial and significant, with a value of 0.196 in the entire model.

Table-7: F-Square

\begin{tabular}{lll}
\hline & JS & OCB \\
\hline EWB ${ }^{*}$ OCB & 0.031 & \\
JS & & 0.345 \\
EWB & 0.119 & \\
OCB & 0.196 & \\
WLB*OCB & 0.016 & 0.103 \\
WLB & 0.055 & \\
\hline
\end{tabular}

\section{Confidence Intervals}

To determine the significance of the Path Coefficient, the CIs (Confidence Intervals) for the constants of the latent elements were estimated using a bootstrap approach. This bootstrap method does not require a normality assumption for the sample distribution. A significant route coefficient exists if zero does not fall in the bottom and top 95 percent of CIS accepts one relationship (WLB*OCB->JS), according to Joseph F. Hair et al. (2019). Table 8 shows that there are no zeros in the bottom and upper 95 percent 
confidence intervals of the current study.

\begin{tabular}{|c|c|c|c|c|c|}
\hline Hyp. & Relationship(s) & $\begin{array}{l}\text { Original } \\
\text { Sample }\end{array}$ & $\begin{array}{l}\text { Sample } \\
\text { Mean }\end{array}$ & $2.5 \%$ & $97.5 \%$ \\
\hline H1 & EWB $\rightarrow$ JS & 0.336 & 0.334 & 0.183 & 0.474 \\
\hline H2 & $\mathrm{WLB} \rightarrow \mathrm{JS}$ & 0.212 & 0.217 & 0.093 & 0.344 \\
\hline H3 & EWB*OCB & -0.171 & -0.165 & -0.314 & -0.008 \\
\hline H4 & $\mathrm{WLB} * \mathrm{OCB} \stackrel{\mathrm{IS}}{\rightarrow}$ & 0.125 & 0.118 & -0.040 & 0.270 \\
\hline EX1 & $\mathrm{EWB} \longrightarrow \mathrm{CB}$ & 0.545 & 0.547 & 0.408 & 0.685 \\
\hline EX2 & $\mathrm{WLB} \longrightarrow \mathrm{CB}$ & 0.402 & 0.399 & 0.249 & 0.542 \\
\hline EX3 & $\mathrm{OCB} \rightarrow \mathrm{S}$ & 0.297 & 0.297 & 0.151 & 0.439 \\
\hline
\end{tabular}

\section{Path Coefficient $(\beta)$ and hypothesis testing}

Additionaly, a crucial T-value $>1.96$ at $\mathrm{p}<0.05$ suggests that the Path Coefficient is statistically significant in a two-tailed test (Hair et al., 2019). Table 9 shows that the t-value is greater than 1.96 and the p-value is less than 0.05 , indicating that the route coefficient of the model in the ongoing study are significant, with the acceptance of one (EWB*OCB JS).

\begin{tabular}{llllll}
\multicolumn{7}{c}{ Table-9: Path Coefficient $(\beta)$ and hypothesis testing } \\
\hline Hyp. & Relationship(s) & $\boldsymbol{\beta}$ & T-value & $\overrightarrow{\mathbf{P}}$-values & Results \\
\hline $\mathrm{H} 1$ & EWB $\longrightarrow \mathrm{S}$ & 0.335 & 4.514 & 0 & Significant \\
$\mathrm{H} 2$ & WLB $\longrightarrow \mathrm{S}$ & 0.212 & 3.317 & 0.001 & Significant \\
EX1 & EWB $\longrightarrow \mathrm{SCB}$ & 0.545 & 7.695 & 0 & Significant \\
EX2 & WLB $\longrightarrow \mathrm{OCB}$ & 0.297 & 4.04 & 0 & Significant \\
EX3 & OCB $\longrightarrow \mathrm{JS}$ & 0.402 & 5.32 & 0 & Significant \\
\hline
\end{tabular}

\section{Moderation Analysis}

Tables 1-3 illustrate that Organizational Citizenship Behavior (OCB) moderated the relationship between Employee Well-Being (EWB) and Job Satisfaction (JS), but not between the Work-Life Balance (WLB) and Job Satisfaction (JS).

Table-3: Moderation Analysis

\begin{tabular}{lllllll}
\hline Hyp. & Relationship(s) & $\boldsymbol{\beta}$ & T-value & P-values & Results \\
\hline $\mathrm{H} 3$ & EWB*OCB & J & -0.171 & 2.172 & 0.03 & Significant \\
H4 & WLB*OCB & J & 0.125 & 1.544 & 0.123 & Rejected \\
\hline
\end{tabular}

\section{Discussion}

The current study that looked at the connections between Employee Well-being, Work-Life Balance, and Job Satisfaction in a sample of 220 professionals from various healthcare centers in Multan region. The point of the study was to decide whether Employee Well-being contributes to their Job Satisfaction of employees with an instinctive sense of Organizational Citizenship Behavior (OCB) as having practiced norm. Besides one, the study's findings supported the hypotheses statements.

In this study, employees with higher levels of Employee Well-being were found to be more satisfied with the organizationally provided Organizational Citizenship Behavior as well as more engaged with their work responsibilities. It could be related to the global excessive high workload pressure in the healthcare centers, particularly among employees (Janssen et al., 2020), who made up the bulk of students in this research. When job demands are high, employees may find it difficult to sustain them effectively. Organizational Citizenship Behavior, in particular, has been found to moderate the relationship among Employee Well-being and Work Life Balance.

Moreover, The research findings give legitimacy to the Theory of Planned Behavior by illustrating the value of having confidence in one's own skills and abilities, as well as intrinsic incentive to participate in the powers and tasks assigned to them by organizations. Intention (true purpose) and ability can both influence behavioral performance (behavioral control). Organizations must evaluate employee Job 
Satisfaction since low satisfaction can induce negative reactions in the workforce, resulting in considerable financial costs. Employee satisfaction has been found to be inversely related to performance, with lower satisfaction resulting in lower performance (Judge, Thoresen, Bono, \& Patton, 2001).

\section{Conclusion}

Our findings imply that healthcare centers should take steps to develop better ways to assist employees in achieving higher levels of Work Life Balance (WLB), which is likely to lead to enhanced Employee Well-Being and thus improved performance. If employees do not establish their own way to improving their well-being, the healthcare centers' efforts will be for naught. Conclusions are critical for practitioners who want to increase their organization's performance by improving Employee Well-Being. Our research responds to a request for more multilevel analyses focusing on Employee Well-Being in various situations (Martin et al., 2016)

By the end of the assessment, it has been determined that Work-Life Balance doesn't really support the moderating relationship between Organizational Citizenship Behavior and Job Satisfaction. According to the assessment report, the moderating link between Employee Well-Being and Job Satisfaction is significant. Meeting employees' needs was a major emphasis of the literature review because it has a beneficial impact on employee well-being. It is crucial to emphasize that trying to ensure Employees' Well-Being premised on sustainability practices helps to stimulate critical thinking, reveals positive social behavior patterns, contribute to improved feelings and effective employee achievement, and enhances team trust as a critical aspect of streamlined performance of the organization. A review of research publications a direct and indirect link between Job Satisfaction and Employee Well-Being. As a result, further research is needed to determine the links between Job Satisfaction and Employee Well-Being, as well as the moderating effects of Organizational Citizen Behavior.

\section{Limitations}

The strength of this study derived from a hierarchical and naturally nested sample from major healthcare centers with a wide range of work units and occupations. By use of cross-sectional data was one of the study's limitations. Second, because we only looked at one organization, findings that were contextspecific would have to be replicated in multiple healthcare centers. This could explain why some people are dissatisfied with management services (which include the customer service). Moreover, current research is limited to a bridge design, making causal inferences for this study difficult. Third, the study sample was comprised of staff working in healthcare centers of Multan region with varying demographic factors and occupational backgrounds; thus, the generalizability of our findings to other industries or sectors remains to be determined.

\section{Future Research Directions}

Supervisory observations and management evaluations of job performance could be used in future studies to validate the statements of results acquired after the statistical analysis of the study. There have been hardly any research and inquiries into the specific impact of such components on work performance. The effects of work overload, psychological well-being, and safety on employee health should also be investigated, with the study observation of Organizational Citizenship Behavior serving as a mediating function. The current study can be replicated, and future studies will need to evaluate the study's findings on both a sample of other healthcare centers in other countries and a sample of other healthcare centers in other countries. Future studies can use the same study approach to validate across a variety of businesses and cultures. The role of these characteristics in regulating the relationship between employee well-being, affective commitment, and job performance may be studied further in the future.

\section{References}

Ahmad, Z. B. (2006). Job attitudes as a determinant of organizational citizenship behaviors: A study among academic staff in Kuching Polytechnic, Sarawak. Unpublished master's thesis, Universiti Utara Malaysia. Retrieved 3 August 2009, from http://ep3.uum.edu.my/96/1/zulaiha.pdf 
Boxall, P., \& Macky, K. (2014). High-involvement work processes, work intensification and employee wellbeing. Work, Employment and Society, 28(6), 963-984. https://doi.org/10.1177/0950017013512714

Daniels,L. and McCarraher,L. (2000) The Work-life manual, London: Industrial Society

Faragher, E. B., Cass, M., \& Cooper, C. L. (2005). The relationship between job satisfaction and health: a meta-analysis. Occupational and Environmental Medicine, 62(2), 105-112.

Ganapathi, I. M. D., \& Gilang, A. (2016). Pengaruh work-life balance terhadap kepuasan kerja karyawan (studi pada PT. Bio Farma Persero/ The impact of work-life balance towards job satisfaction study on Bio Farma Company. E-jurnal Ecodemica,

George, J.M. and Jones, G.R. (2008). Understanding and Managing Organizational behavior, Fifth Edition, Pearson/Prentice Hall, New Yersey, p. 78

Grant A., Christianson M., and Price R. (2007), Happiness, Health, or Relationships? Managerial Practices and Employee Well-Being Tradeoffs, Academy of Management Perspectives, August, pp.51-63

Greenhaus, J. H., Collins, K. M., \& Shaw, J. D. The relation between work-family balance and quality of life. Journal of Vocational Behavior, Vol. 63, Iss. 3, pp. 510-531, (2003).

Griffin R. and Danna K. (1999), Health and wellbeing in workplace: a review and synthesis of literature, Journal of management, 25(3), pp.357-384

Guest, D. E. (2017). Human resource management and employee well-being: Towards a new analytic framework. Human Resource Management Journal, 27(1), 22-38. https://doi.org/10.1111/1748$\underline{8583.12139}$

Hirschfeld, R. R. (2000). Validity studies. Does revising the intrinsic and extrinsic subscales of the Minnesota Satisfaction Questionnaire Short Form make a difference? Educational Psychological Measurement, 60(2), 255-270.

Hair, J., Risher, J., Sarstedt, M., \& Ringle, C. (2019). When to use and how to report the results of PLSSEM. European Business Review, 31(1), 2-24. doi: 10.1108/ebr-11-2018-0203

Hair, J. F., Ringle, C. M., \& Sarstedt, M. (2017). Partial least squares structural equation modeling. Handbook of market research, 26(1), 1-40.

Iaffaldano, M. T., \& Muchinsky, P. M. (1985). Job satisfaction and job performance: A meta-analysis. Psychological Bulletin, 97(2), 251-273.

Janssen, E., Van Strydonck, I., Decuypere, A., Decramer, A., \& Audenaert,M. (2020). How to foster nurses' well-being and performance in the face of work pressure? The role of mindfulness as personal resource. Journal of Advanced Nursing, 76(12), 3495-3505. https://doi.org/10.1111/jan.14563

Judge, T. A., Thoresen, C. J., Bono, J. E., \& Patton, G. K. (2001). The job satisfaction-job performance relationship: A qualitative and quantitative review. Psychological Bulletin, 127(3), 376.

Judge, T. A., Thoresen, C. J., Bono, J. E., \& Patton, G. K. (2001). The job satisfaction-job performance relationship: A qualitative and quantitative review. Psychological Bulletin, 127(3), 376.

Lovell, S. E., Kahn, A. S., Anton, J., Davidson, A., Dowling, E., Post, D., \& Mason, C. (1999). Does gender affect the link between organizational citizenship behavior and performance evaluation? Sex Role, 41(5/6), 469-478.

Martin, A., Karanika-Murray, M., Biron, C., \& Sanderson, K. (2016). The psychosocial work environment, employee mental health and organizational interventions: Improving research and practice by taking a multilevel approach. Stress and Health, 32(3), 201-215. https://doi.org/10.1002/smi.2593

McCarthy, G., Almeida, S., \& Ahrens, J. (2011). Understanding employee well-being practices in Australian organizations. International Journal of Health, Wellness \& Society, 1(1), 181-198. https://doi.org/10.18848/2156-8960/CGP/v01i01/41076

Mishra, S., \& Kapoor, S. (2017). Non-monetary employee welfare activities (strategic move towards changing dynamics of organization). In Proceedings of International Conference on Strategies in Volatile and Uncertain Environment for Emerging Markets (pp. 179-189).

Montgomery, A., Panagopoulou, E., Esmail, A., Richards, T., \& Maslach, C. (2019). Burnout in 
healthcare: The case for Organizational change. BMJ, 366(4774), 14774. https://doi.org/10.1136/bmj.14774

Nunally, J. C., \& Bernstein, I. H. (1978). Psychometric theory

Organ, D. W. (1988). Organizational citizenship behavior: The good soldier syndrome Lexington, M. A.: Lexington Books.

Othman. N. (2002). Antecedent of organizational citizenship behavior. Unpublished master's thesis, Universiti Utara Malaysia.

Page, K. M. and Vella-Brodrick D. A. (2009), The „Whate, „Why ${ }^{\text {ee }}$ and „How ${ }^{\text {ee }}$ of Employee Well-Being: A New Model, Social Indicators Research, 90, pp.441-458 Patton, M. Q. (2002): Qualitative evaluation and research methods (3rded.). Thousand Oaks, CA: Sage Publications, Inc.

Podsakoff, N. P., Whiting, S. W., Podsakoff, P. M., \& Blume, B. D. (2009). Individual-and organizational-level consequences of organizational citizenship behaviors: A meta-analysis. Journal of Applied Psychology, 94(1), 122. (DOI:10.1037/ a0013079)

Qi, D., \& Wu, Y. (2018). Does welfare stigma exist in China? Policy evaluation of the Minimum Living Security System on recipients' psychological health and wellbeing. Social Science \& Medicine, 205, 26-36. https://doi.org/10.1016/j.socscimed.2018.03.041

Rau, B., and Hyland, M. (2002). Role conflict and flexible work arrangements the effects on applicant attraction. Personal Psychology, 55, pp.111-36.

Robertson, I. T., \& Cooper, C. L. (2010). Full engagement: The integration of employee engagement and psychological well-being. Leadership \& Organization Development Journal, 31(4), 324-336. https://doi.org/10.1108/01437731011043348

Rothmann, S. (2008). Job satisfaction, occupational stress, burnout and work engagement as components of work-related wellbeing: empirical research. SA Journal of Industrial Psychology, 34(3), 11-16.

Sarstedt, M., Ringle, C.M. and Hair, J.F. (2017b), "Treating unobserved heterogeneity in PLS-SEM: a multi-method approach", in Noonan, R. and Latan, H. (Eds), Partial Least Squares Structural Equation Modeling: Basic Concepts, Methodological Issues and Applications, Springer International Publishing, Cham, pp. 197-217

Skevington, S. M., Lotfy, M., \& O'Connell, K. A. (2004). The World Health Organization's WHOQOLBREF quality of life assessment: Psychometric properties and results of the international field trial.

Smith, P. C. (1969). The measurement of satisfaction in work and retirement: A Strategy for the study of attitudes.

Wang, Xuequn; French, Brian F.; and Clay, Paul F. (2015) "Convergent and Discriminant Validity with Formative Measurement: A Mediator Perspective," Journal of Modern Applied Statistical Methods: Vol. 14 : Iss. 1 , Article DOI: 10.22237/jmasm/1430453400

Warr, P. (2009). Environmental "Vitamins", Personal Judgments, Work Values, and Happiness. In S. Cartwright, \& Cooper, C. L. (Ed.), The Oxford Handbook of Organizational Well-Being. Oxford: Oxford Handbooks Online.

Warr, P., Cook, J., \& Wall, T. (1979). Scales for the measurement of some work attitudes and aspects of psychological well-being. Journal of Occupational Psychology, 52(2), 129-148.

Williams, L. J., \& Anderson, S. E. (1991). Job satisfaction and organizational commitment as predictors of organizational citizenship and in-role behaviors. Journal of Management, 17(3), 601-617.

Wright, T. A., Cropanzano, R., \& Bonett, D. G. (2007). The moderating role of employee positive wellbeing on the relation between job satisfaction and job performance. Journal of Occupational Health Psychology, 12(2), 93-104. 